\title{
Contemporary Perspectives of Occupational Therapy in Latin America: Contributions to the Glocal Dialogue
}

\author{
Ricardo Lopes Correia. B OT (CUSC); PhD (FMABC). http://orcid.org/0000-0003-3 1 08-2224
}

Professor at Department of Occupational Therapy and Postgraduate Program in Community Psychosociology and Social Ecology, Federal University of Rio de Janeiro, Brazil.

Luciana Gaelze Wertheime. B OT (UFCSPA). http://orcid.org/0000-0003-094 I- I 255

Co-head at AL-Cultura e Conhecimento, Porto Alegre, Brazil.

*Rodolfo Morrison. B OT (UACh); MSc, PhD (USAL). http://orcid.org/0000-0002-2834- I646
Head, Department of Occupational Therapy and Occupational Science, Faculty of Medicine, Universidad de Chile, Santiago, Chile.

Carla Regina Silva. B OT, MSc, PhD (UFSCar). http://orcid.org/0000-0002-7079-8340

Professor at Department of Occupational Therapy and Postgraduate of Occupational Therapy, Cultural Coordinator at Federal University of São Carlos, São Carlos, SP, Brazil.

Background: The contemporary perspectives of occupational therapy in Latin America focus on an epistemic, political, and plural field under construction and in dispute. It is about the notions of knowing and doing designed to appoint the theoretical and methodological aspects that support the reading and intervention of the complex realities.

Purpose: This paper explores a glocal dialogue about the production and dissemination of knowledge in occupational therapy in Latin America.

Key issues: The dialogue includes issues and trends in the global scientific and social scenario, without neglecting aspects of different local realities around the world. By focusing on the profession in Latin America, using different perspectives, such as Critical Occupational Therapy; Occupational Therapy and Social Issues; Occupational Therapy and Culture; Territory and Community Occupational Therapy; Southern Occupational Therapies; and Occupational Science in Latin America. It further discusses the relationship between the theoretical perspectives and the coloniality of knowledge in occupational therapy and the contradictions based on neoliberal models in the production and dissemination of knowledge.

Conclusion: The hegemonic neoliberal model and the glocalisation theoretical framework appeared to support and circumvent the production of scientific knowledge in occupational therapy, and placed Latin America on the periphery of the global debate.

Keywords: professional practice of occupational therapy; theoretical framework, theoretical perspective, coloniality of knowledge, critical occupational therapy, occupational science.

\section{INTRODUCTION}

The contemporary perspectives of occupational therapy in Latin America comprise a plural epistemic-political field that is in dispute over designating the theoretical and methodological aspects that support the reading and intervention in the complex realities of the various regions where occupational therapists perform their varied practices. An understanding of the thinking-knowing-doing skills of occupational therapy in Latin America is guided by the structural issues of its socio-cultural territory, and to identify paths for a global debate in the area. This relationship is directly related to the practices and actions developed to meet specific demands of this unique, plural, and diverse territory - which has immense cultural wealth and historical processes marked by the patriarchal system, colonialism, global coloniality, slavery, exploitation, submission to the richest and most central countries and the detrimental effects resulting from neoliberal capitalism'.

It seems that occupational therapy in Latin America makes a great effort to create and articulate epistemic structures for local action, which do not gain their proper place in the global context. The concept of "glocal" is important because it comprises the tensions and challenges in dialogue and action on the production and dissemination of knowledge in occupational therapy. 'Glocal' is a concept that refers to a specific way of thinking and acting on how contemporary socio-political issues in the globalized world are directly involved in the symbolic and material (re)production of local everyday life, and vice versa ${ }^{2}$. In both Occupational Therapy and Occupational Science disciplines, the concept of "glocal" is not explored widely enough to operate the local and global dimensions in an inseparable way. However, criticisms about the relationships between the production of care and local knowledge under globalisation trends are already observed in more critical perspectives, especially when dealing with social, cultural, and environmental issues involving the disciplines of Occupational Therapy ${ }^{3}$ and Occupational Science ${ }^{4}$. 
This paper does not intend to point out a single 'Latin American' identity for occupational therapy. On the contrary, it corroborates the dangers of a single history ${ }^{5}$ and presents some theoretical and methodological perspectives developed by Latin American occupational therapists. In this way, the debate is broadened, and the understanding and the voices of what has been understood as occupational therapy emerge as they have important contributions to the glocal dialogue of the field. As a profession and an area of knowledge, occupational therapy has been present in Latin America since the 1950s, especially in South American countries ${ }^{6}$. Respecting the singularities and pluralities of each territory, the first decades of occupational therapy in this region were marked by practices aimed at maintaining the status quo, namely that of subjects' alienation, behavioural adaptation, economic maintenance of institutions through work, especially agricultural work, and the development of skills disconnected from the social reality ${ }^{3,4}$. In this way, the 'knowing' and 'doing' were essential to support times of transition and the new practices addressed in response to global and local demands and realities.

Since the beginning of the 1920s, with a resurgence in the 1960s, civil-military dictatorships in Latin America, although not present in all countries in the region, marked important socio-historical, political, and economic processes based on forms of government based on violence and in the silencing of any critique toward the power of the State 6 . However, in the 1970s in countries such as Argentina, Brazil, Chile, Colombia, Mexico, and Venezuela, social movements in favour of political re-democratization were observed $^{7}$. Therefore, a new scenario emerged from a change in the attitude of occupational therapists, who started to act locally, in a more engaged and critical way, based on the understanding of global, macro-social issues, such as human rights, sustainability, perverse impacts of neoliberal economic models on the daily lives of different populations, public policies as an instrument of social protection and citizenship, among others. This process included an epistemic turn in occupational therapy in Latin America, and modifications and expansion of its theoretical-methodological perspectives as the insufficiency of traditional and institutionalized practices were being recognised. Thus, it is during the process of re-democratization of Latin American countries that we can recognize an occupational therapy centred on the defence of citizenship and its value as a political, civil, and especially, social rights.

Given this, this article selected contemporary theoretical and methodological perspectives of occupational therapy which are specific to Latin America, as well as interpretations and adaptations of knowledge from other regions that have been incorporated in response to their own demands and realities. New interpretations and adaptations of knowledge in Latin America represent a glocal strategy, for example, in the case of the discipline of Occupational Science and other areas of interdisciplinary knowledge that add criticality to the nature of the occupational therapy discipline, as well as specific and local forms of acting professionally. To this end, we start from the selection of perspectives that break the epistemic domination of the 'international' occupational therapy present in Latin America, considering the documented and disseminated perspectives in the field, together with those disseminated through the main scientific journals, books, theses, and in communication spaces such as scientific events. In this sense, the efforts of political organisations of occupational therapy in the region concentrate on the efforts of holding meetings and events periodically, which encourage debate and actions of the professional category in political, academic, technical, and professional arenas.
Between the contours and possibilities that have been part of occupational therapy in Latin America, it is worth highlighting the concern and centrality present in care for people, groups and collectives considered underlings from the reading and approach of notions about human experience, occupations, and activities in social daily life. Such notions involve essential precepts such as rights, citizenship, social participation associated with the expansion of action to sectors and interface fields beyond health - including, therefore, society, education, culture, environment, and justice. The issue put up for debate is that knowledge of occupational therapy in Latin America is undoubtedly employed as a device of social transformation for the area itself, as well as for society in general. Therefore, this paper proposes a glocal debate on the production and dissemination of knowledge in occupational therapy.

\section{Contemporary perspectives evident in Latin America}

Six contemporary perspectives of occupational therapy in the Latin American region are discussed (I) Critical Occupational Therapy; (II) Occupational Therapy and Social Issues; (III) Occupational Therapy and Culture; (IV) Territorial and Community Occupational Therapy; (V) Southern Occupational Therapies; and (VI) Occupational Science in Latin America. The characteristics enabled the identification of critical questions about the production of knowledge, structures, and tools, in relation to a coherent glocal perspective.

\section{Critical Occupational Therapy}

The denomination 'Critical Occupational Therapy' seeks the critical positioning of a discipline relevant to society, founded on a critical paradigm, based on human dignity, ethics, and the ability to transform society ${ }^{8}$. In addition, it seeks to analyse local and global perspectives in the sense of problematizing and permanently reflecting on the issues in the field and of pressuring the hegemonic foundations. In this way, it unveils the existing power relations in what has been produced in the discipline?

What is important here is the understanding of the ways through which the neoliberal system reduces the political role of the State to administrative functions in which social participation and citizenship as fundamental rights are denied. These, in turn, will question the interests of occupational therapy, especially its technical-social role which, instead of reproducing the model of oppression, seeks to transform the material conditions of daily life that will enable liberating actions.

The discipline of occupational therapy can be a device of control when it hegemonically considers the 'functional forms' for the 'adaptation' of people to the environment, reproducing the logics of the dominant Anglophone models. The idea of seeking a balanced integration with the social system, which is considered the ultimate goal, can uncritically disregard that it is exactly this system that is the impeding factor of people's capacity to realise life and social participation, especially the most vulnerable. Therefore, the positivist production of the discipline is mostly questioned in its rationality centred on the dysfunctional and liberal individual ${ }^{7-9}$. In this scenario, occupation would operate externally and would be the only way of interaction between the individual and the social environment ${ }^{7}$.

In addition, Critical Occupational Therapy considers that knowledge in the field is the result of both research and practice and are equally important, hence ensuring a direct relationship between science and ethics. This positioning breaks with old dichotomies regarding the position of knowledge and practice as isolated entities, as well as the position of local versus global knowledge ${ }^{8}$. Thus, 
Critical Occupational Therapy in Latin America proposes alternative ways to the neoliberal system with the aim of understanding the issues that challenge the discipline. Doing this, it renders it more socially responsive and less depoliticised as defending diversity, justice, and ethical-political commitment is non-negotiable ${ }^{10}$.

Some occupational therapists. in Latin America have positioned their theoretical and methodological frameworks to confront the hegemonic processes of exclusions, violations, and inequalities, such as the production of daily life and the insurgencies of the social fabric $^{7}$, the critical community perspective ${ }^{9}$, and the cultural critique, decolonial and other intersections like gender, class, and race $\mathrm{e}^{\mid l-14}$.

\section{Occupational Therapy and Social Issues}

Social issues related to the unequal and asymmetric expressions of making and conducting material and symbolic life, include poverty, the absence of economic and social opportunities, lack of protection of public policies, and urban and housing precariousness ${ }^{15,16}$. These issues influence the structuring of the social fabric in which people, groups and populations build their daily lives through involvement in occupations and activities.

Social issues in Latin America gained prominence at the end of the 1970s. In this period, the processes of re-democratisation in some countries and the movements for health and psychiatric reform produced a context marked by critical openness and technical and epistemic positions on the social role of the State, institutions, professionals, and the collectivist and social movements ${ }^{17}$.

The next two decades featured experiences of occupational therapists and academics in the social and community field, from practices engaged in economic, social, and cultural issues that produce asymmetries and inequalities in the daily lives of people, groups and collectives. The debate on social issues was initially based on theoretical supports from the human and social sciences, aiming to reflect on macro-social structures and the production of theories and methodologies for action in occupational therapy ${ }^{18}$. From a social perspective, there is the possibility of a renewed view of the practice of occupational therapy, oriented towards the access to rights and the strengthening of support networks for socially vulnerable people, distancing itself from the health-illness binomial in force until then ${ }^{17}$.

At the end of the 1990s, specifically in Brazil, experiences in the social field began to be institutionalised in universities through research and extension projects, corroborating the definition of theoretical and methodological contributions which over time, allowed the institutionalisation of a sub-area of knowledge called Social Occupational Therapy ${ }^{19}$. For this purpose, it developed its own theoretical and methodological landmark to address the marginalisation and disruption of social support networks of groups in processes of vulnerability, from Marxist socio-historical perspectives $^{20}$. This sub-area of knowledge seeks to understand the place where people live and their material, historical and collective dimensions through strategies designed to overcome the structural limits experienced by certain individuals and groups.

It is also important to highlight that in Brazil, the Federal Council of Physical Therapy and Occupational Therapy ${ }^{21}$, which is the State body that regulates the profession in the country, has recognised and established the guidelines for the discipline of occupational therapy specialisation in social contexts since $20 \mathrm{II}$. This period coincided with the regulation of the insertion of occupational therapists in Brazil's Social Assistance policies. In this way, Brazil differentiates itself from other countries in Latin America by inserting the profession in sectors of society beyond the technical area in health expanding the profession to other areas of expertise.

The historical importance of this process is that the theme of social exclusion and the debate about the role of occupational therapists in breaking away from old notions and in facing violations of social and human rights is present in practices in the most diverse action contexts, together with the consequences that interfere in their performance and social participation ${ }^{10,11,22}$. It is also possible to observe the dissemination of actions, concepts, reflections, and practices that have reached different people and marginalised groups such as the work done with migrants, refugees, in the defence of the right to come and go and human mobility, understood as a cultural dynamic, anchored in social and human rights ${ }^{23,24}$.

\section{Occupational Therapy and Culture}

Culture has been a central theme in the debate of occupational therapy and occupational science today, as it is in tune with the glocal (re)discussion processes about diverse aspects of culture in relation to the globalised world. There is an urgent need of a debate about interculturality and cultural hegemony ${ }^{25,26}$ in order to understand and respect human diversity. Such debate will discuss the interaction between cultures under reciprocally equitable terms, favouring their coexistence and integration in a relationship based on the respect for diversity and mutual enrichment.

The dimension of culture, embracing the concepts of human rights and cultural citizenship, has been addressed by occupational therapists, especially in Brazil, establishing occupational therapy practices in the field of culture and cultural policies with different people and population groups to expand the scope of action, and consequently, of knowledge production ${ }^{13}$. In this context, management, production, fruition, and cultural accessibility have been guided by occupational therapists interested in the expansion of this sector, ensuring culture as a right ${ }^{13,27}$. This is another aspect that enables us to verify, unlike other Latin American countries, the importance of knowledge production and communication that allow the insertion of occupational therapy in other technical sectors of care and services.

In general, cultural perspective is based on the possibilities of care, emancipation, participation and citizenship of multiple subjects and groups committed to the expression and power of life $^{28}$. It encompasses the right to diversity and plural ways of life, of interculturality as an ethical, aesthetic, and ancestral commitment, strengthening spaces for the joint creation of strategies to overcome violations and human degradation ${ }^{29}$. When culture is approached as a polysemic concept, the citizen, symbolic and economic dimensions are highlighted, as well as its possibilities of designing counter-hegemonic propositions ${ }^{13}$. It is noteworthy that since the 1980s culture has been understood as essential for the transformation of any society and the main element to be considered for development, especially in the awareness of a society ${ }^{30}$.

Given this, the performance of occupational therapists should be to advocate for the emancipation of people and communities, with commitment and engagement in care, in otherness, with the life events of subjects who mostly suffer the effects of these interrelated systems of oppression ${ }^{13}$. It is also important to emphasize the strengthening and defending cultural rights from the symbolic existence to the dimension of creation and access to cultural goods. To promote cultural accessibility, cultural policies and citizenship have been the focus of occupational therapy. This assisted occupational therapists to stand up for the intersection of knowledge in the fields of public policies, human rights, assistive technology, disability studies, cultural management, museology, and creative 
and expression processes ${ }^{31}$.

Another perspective of occupational therapy that resonates with the studies and practices that involve the virtualization of daily life, is cyberculture. This perspective provides the ways occupational therapy can contribute to the understanding and care which are necessary when dealing with the problems and demands that arise from the exclusion of people from information and communication technology in their daily lives ${ }^{32}$. We can also add reflections about the barriers to the communicational processes involving cultural, economic, geographic, and technological dimensions and the therapeutic and occupational performance in relation to concepts such as justice and occupational injustice, occupational deprivation, and even the occupational apartheid related to thinking and acting on the right to communication ${ }^{33}$.

\section{Territory and Community Occupational Therapy}

Occupational therapists consider community-centred practices such as community development essential practice domains in different parts of the world, in Latin America community development is strongly embedded in occupational therapy practice ${ }^{34}$. During the process of re-democratisation of Latin American countries, the profession of occupational therapy embraced this opportunity and implemented a more critical reading of the social and territorial inequalities of the region which imprint precarious material ways of life on the daily lives of diverse populations ${ }^{35}$. It will be in this context, according to Bianchi ${ }^{18}$, that Latin American occupational therapists will engage in the socio-political issues of their countries, understanding these issues as determinants of their knowing and doing, assuming a more critical production of knowledge and a more responsive technical action to territorial and community issues.

These processes will enable occupational therapists to leave institutions, assuming territory, (urban and rural spaces, public and private spaces) as organising elements of a more socially engaged reasoning. This happened, therefore, from new theoretical readings of Sociology, Anthropology, Philosophy, as well as the creation of more situated methodological tools to operate the territory and community, as a sociocultural phenomenon of production of meanings and forms of collective organization in a given territory ${ }^{36}$. It is in this sense that the literature on Occupational Therapy in Latin America demonstrates a strong convergence of territory and community related to intervention aimed at social participation ${ }^{37}$. Therefore, one can say that the community becomes, in Latin American occupational therapy, a category of analysis about the internationalities and ways of acting collectively in the territory ${ }^{38}$.

Based on this understanding, the literature in occupational therapy in Latin America, especially since the 1990s, has begun to incorporate theoretical and methodological contents from the Social Sciences, as well as from Social and Community Psychology, highlighting the importance of territory and community practices as an inseparable pair ${ }^{39,40}$. It also tries to get rid of the notion of community as a simple group of people marked by the stigma of poverty. It recognizes that it is in the context of social and territorial inequalities that the potential for collectiveaction is constantly threatened. Therefore, it makes sense that therapeutic occupational approaches are oriented to articulate and offer possibilities for cohesion of the social fabric when such subjects experience socioeconomic vulnerabilities ${ }^{38}$.

Having social participation as the key element of reflections and practices in territory and community occupational therapy, we can point out significant contributions to this debate in the works done by Latin American occupational therapists ${ }^{4}$.
The 'Community-based Rehabilitation' movement was very important for the development of practices in different areas throughout Latin America, especially for occupational therapy. It is a system that seeks to break down sectorial barriers and is integrated into community development programmes. It further encompasses as a set of activities and resources aimed at the achievement of a specific objective in each community, in search of democratization, expansion of rights, and equity in functional diversity ${ }^{42}$.

Occupational Therapy with Traditional Peoples ${ }^{43}$ and Communities ${ }^{44}$ introduces the concept of traditional occupations as a specific action of native peoples related to land use, based on their memories and traditions, as well as a social right that defends the (re)existence of this way of acting. The Occupational Therapy of Teaching in Participatory Local Development ${ }^{3}$ is an approach which supports collectives in the organisation and resolution of their territorial demands from Collective Life Projects. Everyday Urban Mobility ${ }^{45}$ (which refers to the circulation and use of the territory of the city, especially of young peripheral urbanites), aims to build, together with the community, strategies for mapping, designing projects and uses of the city. Palácios ${ }^{40}$ incorporates collective occupations in the debate, as historical expressions of the forms of organisation in the territory and of the production of senses of community. Additionally, Paganizzi ${ }^{46}$ discusses natural disasters and the importance of community work in occupational therapy in dealing with psychosocial issues arising from daily disruption.

\section{Occupational Therapies of the South}

Occupational Therapies of the South draws upon the "North-South" understanding stated by Santos ${ }^{47}$ to exemplify the play of contrasts between dominant and subjugated practices, respectively. In this sense, the global South moves from a geographical concept to be applied as a metaphor for human suffering caused by global capitalism, colonialism, and the patriarchal system of power, as well as the resistance to overcome or minimize it ${ }^{48}$.

In this way, the proposal of Occupational Therapies of the South seeks to break with the traditional scheme of practice and the hegemonic theories that respond, reproduce, and maintain the logic of domination of the axes of power. Therefore, the need to identify and build occupational therapies instead of a Eurocentric/ capitalist/colonial/patriarchal identity, as a political and ethical act of rebellion, invites a discussion about the need for theories and practices that are situated, committed, and engaged with social reality. "An OT that is at the service of the excluded, the subaltern, the marginalized, and the oppressed for the purpose of transforming the conditions of oppression and domination"48:673.

This perspective breaks with the division between theory and practice, as it recognises multiple insights resulting from different and possible encounters. It implies emphasising different sets of knowledge, such as "experiential, intuitive, practical, creative, relational, and of common sense, produced in a collective and participatory manner with subjects and communities" $48: 674$. These can be understood as 'trans-knowledge', which allude to the recognition of the knowledge of a subject or of a community in an ontologically equal relationship, represented by its constructions, ideas, experiences, memories, etc., valued in the same way as other knowledge, for example, those from scientific rationalities ${ }^{49}$. It is, above all, an ethical-political position in the face of the circumstances of life that have to do with suffering and injustice, an invitation to produce theoretical-practical processes of transformation and resistance, and to promote the decolonization of occupational therapy, a rescue of the roots and ancestry as a political act, and, necessarily, by a 
feminist, anti-cis-heteropatriarchal, anti-racist, and anti-imperialist position of the profession ${ }^{50}$.

\section{Occupational Science in Latin America}

There are distinct perspectives on occupation and human activity in Latin American occupational therapy. These perspectives coexist and dispute narratives about the object and processes of occupational therapy, which for a little over three decades have centralized the debate about the foundations of the field in the Latin American region ${ }^{51}$.The discipline of Occupational Science is still emerging in the region and there are many reasons for this, such as conceptual and epistemological difficulties, adverse sociopolitical realities, and differences from what has been produced in English-speaking countries. However, considering the potential of Occupational Science, it is possible to highlight the development and contributions that have been made in countries such as Chile, Colombia and very recently in Brazil ${ }^{51}$.

Chile was the first country in Latin America to have an organisation on Occupational Science - the Chilean Occupational Science Society (SoChCO in Spanish) and has made an important intellectual contribution to the subject ${ }^{52,53}$. SoChCO has focused its efforts on establishing a perspective that universalizes theoretical and practical outputs, while at the same time safeguards knowledge about the reality of the Chilean context $\mathrm{t}^{52}$. In the literature of the region, as in the publications of Álvarez et al. ${ }^{54}$ and Carrasco and Olivares ${ }^{55}$, the development of a proper concept of occupation is sought. In previous studies, a discussion about dialogues between public policies and the occupations of people, groups and communities from critical perspectives were reported ${ }^{56-58}$. Meanwhile, authors such as Caro-Vines ${ }^{59}$ and Muñoz ${ }^{60}$ seek to historically rescue the practices and epistemologies around occupation in decentralized spaces of Chilean regionalism. Avillo et al. ${ }^{61}$ and Morrison et al. ${ }^{62}$ reflected on the different forms of oppression and how these manifest in daily occupations.

To this end, the Social Paradigm of Occupation emerged as a new theoretical framework in the search to understand people, groups, and communities in a transactional and interdependent relationship, to overcome the person versus environment dichotomy ${ }^{63}$. It provides a significant contribution that enables us to think of Occupational Science as a field of study focused on relevant aspects in the understanding of occupation, namely, that it is systemic, complex, political, cultural, coherent with health, justice, and the well-being of people and communities ${ }^{63}$.It is also worth pointing out the important contributions made by a group of researchers from the National University of Colombia, entitled Occupation and Human Achievement ${ }^{64}$. From their studies and research, this group created a model called Realizable Occupational Performance with theoretical constructs capable of responding to local and regional aspects, whether in the social, political, cultural, and ecological spheres, perceiving occupation as a process that is in constant dialogue with daily actions.

In Brazil, there are several universities that have worked on themes linked to studies on occupation, such as the Federal University of São Carlos, the University of São Paulo, the Federal University of Minas Gerais through the Graduate Programme on Occupation Studies, and the Federal University of Pará through the Occupation Science Studies Laboratory ${ }^{51}$. We also highlight the efforts in respect to other theoretical and methodological perspectives regarding human occupation that have been employed in Brazil, namely the Laboratory for the Study of Human Occupation and Participation Technologies in Occupational Therapy at the Federal University of
Rio de Janeiro and, from another perspective, the Human Activities and Occupational Therapy Laboratory at the Federal University of São Carlos ${ }^{51}$.

There is no doubt that important studies on Human Occupation have been carried out in several Latin American countries, in many diverse areas. These studies were conducted by engaging with the communities with ethical and political commitment, and included diverse studies and reflections which incorporated new groups of participants, and contributed a new understanding of occupational therapy ${ }^{65}$.

\section{DISCUSSION}

The insights into the perspectives presented in the previous sections demonstrated that there are some Latin American opportunities for dialogue with the global scenario of occupational therapy. These include, to some extent, practices and knowledge generated by occupational therapists which arose from specific issues in the realities within the Latin American context, allowing us to highlight some key concepts and issues of interest to the "world-system" of occupational therapy, Thus, among the various shades of historicalpolitical-cultural issues that culminated in 'specificities of the Latin American region', we highlight for discussion those that are placed as 'contradictory' and 'impeding' to the 'international advancement' of the area and the global dialogue, especially the coloniality of power, knowledge and being in occupational therapy and the implications for the production and dissemination of knowledge in the area ${ }^{8}$.

Quijano ${ }^{66}$ uses the term 'coloniality of power' to express the power relations and subjugations in the economic and political spheres still prevail after the end of colonisations. For Mignolo ${ }^{67: 12}$, it is "a complex structure of intertwined levels" that regulates the control of the economy, authority, nature and natural resources, gender and sexuality, subjectivity, and knowledge, and therefore is necessarily articulated with the colonialities of power, knowledge, and being. From this perspective, when we do not claim that "we are occupational therapists from a culturally specific region, such as Latin America" and we do not include ourselves into the identity markers of the people and groups with whom we work, we are repeating the refined strategies of coloniality. 'Race' and 'racism' is emphasized in this approach since it must be understood as "the organising principle that structures all the multiple hierarchies of the world-system"::123.

The recognition of knowing and doing has come a long way in terms of historical debt and reparation about the deep meaning of human occupation and activity, especially for those who suffer the most from the ruptures and scars of a process of domination that remains active, refined, and very well-articulated even to this day. Given this, it is necessary to question some important features such as: what are the parameters and measures adopted in the international-global context for judging what is produced in the field of occupational therapy? Which perspectives are validated and what is our understanding of non-hegemonic systems? The colonialities of power was supported by the coloniality of knowledge. "Epistemic colonial difference is complicit with universalism, sexism, and racism" "6:104. Thus, what is unveiled is the construction of a dominant and unjust narrative in the ways global knowledge in occupational therapy is produced and disseminated, as the asymmetries of local reality are not placed under the analysis of this emerging task.

There is a profound contradiction in the production and dissemination of knowledge in occupational therapy, especially in Latin America - that of trying to respond to the demands of the global scenario with the same tools it fights against: the tools of the hege- 
monic neoliberalist system which operates through a domineering and hierarchical knowledge system. The discourse that presents the neoliberalist system as exclusionary and genocidal, evokes a more critical and responsive occupational therapy and does not find support in the conditions for producing and disseminating counter-hegemonic knowledge. Therefore, occupational therapy ultimately surrenders to the modus operandi of sciences in the scientific publishing market which places it in a peripheral position in the scenario of international knowledge production.

The publishing market came into existence in the late eighteenth century in Anglo-Saxon countries, especially in the United States of America, England, and in Germany ${ }^{69}$. The last two decades saw the advance of this market as a highly profitable asset that has become the compass of scientific quality production and evaluation. Between 2016 and 2017, companies like Elsevier profited more than $\$ \mathrm{I}$ billion, more than companies like Facebook and Google. The price to submit and publish in one of the journals in the Nature collection, for example, can be as high as 9,000 euros ${ }^{69}$. The demands that boost the scientific publishing market are based on the weaknesses and impediments, of especially the peripheral countries regarding achieving internationalisation ${ }^{69}$. In turn, the discourse of internationalisation, set by the publishing market itself, consists of the search for a common denominator related to the English language, the evidence model based on the medical and natural sciences, and metrics in bibliographic and socio-metric production based on journals indexed in the databases of private publishing groups.

It is also important to highlight that the publishing operation system capitalized by these large commercial companies takes place under a perverse logic which has been increasingly launched to science makers (scientists). According to this logic, it is the scientists who must pay for the dissemination of their knowledge, based on the discourse that public and private funding should be the main funders of their research. However, there are two contradictions in this narrative. The first consists in the free delivery of the product of knowledge to the publishing company. Thus, publishers do profit from raw material that was delivered to them at no cost, and charge those who produced it to "qualify and disseminate it". The second contradiction consists in the decrease of the role of the State in guaranteeing the means to produce knowledge. For while the State, the main investor of research in Latin America through its Public Institutions use the metrics and tools of private publishers to evaluate local scientific production, they base their funding criteria in the interests of publishers rather than on public and local demands. Studies demonstrate that occupational therapy in Latin America advocated for the dissemination of knowledge specific to the area ${ }^{70,71}$. One can observe, for example, scientific journals created in the 1990s and their long path of confrontation to adapt their production to international indexing requirements, one of them being the charging of financial costs to authors for the publication of articles.

In this context, the representation and modes of operation of the English language as a compulsory matrix of international science stand out. However, more than a simple language translation, what we have observed, is "the use of English as cultural modus operandi" to produce and disseminate science. Today, to achieve good indexing and a high impact factor, several scientific journals 'encourage' non-English-speaking authors to write articles that an English-speaking person can understand. For this, the use of a wide vocabulary, grammar and semantics are necessary to adapt the work to the English-speaking reader. Additionally, this means abandoning the specificities of content and form of the knowledge productions of the so-called "non-Anglophones". It is exactly in this operation, one of denying the cultural specificity of the way local knowledge is produced and disseminated, that the publishing market causes the death of an original, specific, and diverse knowledge that could contribute to socio-global changes via the sharing, recognition and replication of data, theories, and methods outside the Anglophone context.

From a critical reading of the biased publishing market that is evident in the dissemination of knowledge in occupational therapy, as well as in science in general, it is possible to understand it as a hegemonic device for the control of knowledge in the area that hinders or narrows the global dialogue. The criteria (such as the English language as a universal language, the use of references from journals indexed in databases with impact metrics, the use of classifications, terminologies and research methods), contribute to creating barriers to a broader dialogue. In this sense, it is not only the content of knowledge in occupational therapy that is at stake in this scenario, but also the mechanisms of the operating system that produces and disseminates it. Thus, it is necessary to recognize that the possibilities for dialogue in global occupational therapy are imbedded in this theme, and to not recognize it and, above all, to not modify it, may represent, as it has long represented, the epistemicide of occupational therapy in Latin America.

\section{Weaving 'glocal' dialogues in Occupational Therapy}

From the tensions exposed between local and global knowledge in occupational therapy, what does this article propose?

We feel as though we are loose in a cosmos empty of meaning and unaccountable for an ethic that can be shared, but we feel the weight of that choice on our lives. We are warned all the time about the consequences of these recent choices we have made. And if we can give attention to some vision that escapes this blindness, we are experiencing all over the world, perhaps it can open our minds to some cooperation among peoples, not to save others, but to save ourselves ${ }^{72: 44}$.

There are different epistemologies in occupational therapy being produced in Latin America which recognises subjects situated in highly specific realities ${ }^{73}$. This has allowed occupational therapists to implement processes that effectively protect well-being, quality of life and social rights from of the effects of colonization.

We believe that the global scenario of knowledge in occupational therapy should be an expanded arena of distinct sets of knowledge instead of a scenario of incessantly searching for common denominators in something which cannot be minimised - the local occupational experience of human beings. In this way, the "glocal" strategy of production and dissemination of knowledge seems appropriate to our aims. This strategy comprises a dialogue that recognises the importance of globalisation as a phenomenon that brings realities closer together and connects experiences. However, at the same time, it values the local dimensions of knowing and doing in occupational therapy and takes its position from there.

The origin of the concept of 'glocal' is quite uncertain, but it can be identified in feminist studies ${ }^{74}$, in the field of local development ${ }^{75}$ and in intersectional studies on health and environmental issues ${ }^{4}$. Furthermore, the concept serves as a mechanism for cognitive change over reality and, therefore, for interference in the ways of operating it. The changes at the local level interfere with global structures and dynamics and vice versa'. As such, it draws attention to the interrelationship of dimensions or levels of reality that are not hierarchical because they are distinct and interdependent. However, 
in this dialogue of production and the experience produced in the different dimensions are considered opportunities to recognise and operate fundamental theoretical and methodological elements for dialogue and development in the field of occupational therapy.

The notion of glocal dialogue about knowledge in occupational therapy would then involve the acknowledgement of the narratives produced about the realities and areas of interest in the field, dispute among themselves, and especially, coherent ways of existing. Thus, terminologies, concepts, constructs, theories, models, and approaches need to be understood within their local epistemic realities and have to be validated from this perspective. As a result, they will undo the processes that tend to determine the universalizing and hegemonic referential that do not respond to diverse realities.

As an opportunity to expose strategies that strive to produce a glocal dialogue about the production and dissemination of knowledge in occupational therapy, the Amaru network has been growing since $2017^{12}$. This network comprises a space for identification, production, sharing and dissemination of knowledge in occupational therapy in Latin America. The Amaru network derives from the Quechua language of the Andean culture, which means fluid, open knowledge, and is represented by a two-headed snake that metamorphoses according to changes in the environment ${ }^{12}$. The network arose from the determination of some professors, researchers, and occupational therapists, particularly from Brazil, Chile, and Argentina, to broaden the debate about the knowledge about the Latin American region. After the IXth Meeting of Occupational Therapy Schools of Latin America in Mexico City in 2017, a series of actions were initiated that expanded on the proposal for the construction of the network among colleagues and students in the area. This provided more meeting spaces, such as during the ${ }^{1}$ Meeting of Occupational Therapy of the South, in Santiago, Chile, in 2018, and in the $\mathrm{XI}^{\text {th }}$ Meeting of Schools and XIII ${ }^{\text {th }}$ Latin American Congress of Occupational Therapy in the city of Tucumán in Argentina, in 2019.

Currently, the Amaru network meets periodically to coordinate strategies for approaching occupational therapists in the region and identify the knowledge produced, both those from the academy and from clinical practices and other contexts that add knowledge and value to occupational therapy, such as the esthetical-artistic, community and social movements. There is a team of students who collaborate with the network in the construction and production of content for social networks as a communication strategy. In addition, the Amaru Network is conducting a survey to map the knowledge produced by occupational therapists with the data produced, an open and continuous repository will be created, to be a search reference mechanism for the region itself, as well as for the global dialogue in the area. The Amaru Network, therefore, proposes an engagement to glocal dialogue, creating collective and networked tools, supported by a decolonizing the perspectives on knowledge and in the paradigm of Open Science.

\section{FINAL CONSIDERATIONS}

Glocal dialogue and action of and about the production and dissemination of knowledge in occupational therapy are still imperative challenges in Latin America. The greatest challenge facing us is overcoming the Anglo-Saxon hegemonic mechanisms of the scientific system, also reproduced in the region, which seems to be the trajectory of the internationalisation of occupational therapy. This has led to the epistemicide of local knowledge of Latin American occupational therapists. Even so, there is a series of theoreticalmethodological perspectives that act as legitimizing devices for an intensely rich and diverse field of knowledge and practices in occupational therapy. These perspectives are coherently grounded in the territorial, cultural and political realities of Latin America.

Favouring the plurality of knowledge connected to the problems and urgent demands from diverse communities that integrate the practices of occupational therapists, demands epistemic disobedience $^{9}$ to provide coherent, conscious, situated and engaged responses with the transformation of these realities. Beyond this experience, the more detailed identification of other ontoepistemological assumptions, as well as of collective movements of occupational therapists in Latin America, should be disseminated in future studies, allowing the identification of the limits, the central concepts of each and their counter-hegemonic mechanisms for action and confrontation. The latter may favour a discussion more linked to the philosophical-political-ethical sphere regarding the local practices of occupational therapy in Latin America and their contributions to the global scenario.

\section{Conflicts of interest}

The authors declare that there was no conflict of interest in this study.

\section{AUTHOR CONTRIBUTIONS}

All authors were responsible for elaborating the conception of the text. They wrote the entire article and approved the final version.

\section{REFERENCES}

I. Grosfoguel R. Decolonizing Political-economy and Postcolonial Studies: Transmodernity, Border Thinking, and Global Coloniality. Revista Crítica de Ciências Sociais. 2008;80: 1 I5-47. https://doi.org/10.4000/rccs.697

2. Somekh N. Construção social da cidade: desenvolvimento local e projetos urbanos [Social construction of the city: local development and urban projects]. In: Dowbor L, Pochmann M, editors. Políticas para o desenvolvimento local [Policies for local development]. São Paulo: Fundação Perseu Abramo; 2008.

3. Correia RL. The reach of occupational therapy in local development. Cadernos Brasileiros de Terapia Ocupacional. 2018;26(2):443-62. https://doi.org//0.4322/2526-89/0.ctoAOII82

4. Persson D, Erlandsson L-K. Ecopation: connecting sustainability, glocalisation and well-being. Journal of Occupational Science. 20 I4;2 I ( ): I 2-24. https://doi.org/ I0.1080/I442759I.20I3.86756 I

5. Adichie, C. N. (2009). The danger of a single story. Ted. Conference available in: https://www.ted.com/talks/chimamanda_ngozi_adichie_the_danger_of_a_single_story

6. Santos VD, Gallassi A. Questoes contemporáneas da terapia ocupacional na América do sul Contemporary issues of occupational therapy in South America]. Curitiba: CRV; 2014.

7. Galheigo S. Towards Critical and complex perspective of Occupational Therapy, activity, daily life, diversity, social justice and ethical and political commitment. TOG (A Coruña). 20I2; 5:I76-87.

8. Lerdo de Tejada P. Sobre la construcción de conocimiento de la Terapia Ocupacional chilena. Una puesta en escena sobre la producción de conocimiento de la última década [On the construction of knowledge of Chilean Occupational Therapy. A staging of the knowledge production of the last decade]. Santiago: [Thesis] Magíster en Terapia Ocupacional. UNAB; 2016.

9. Morán JP, Ulloa F. Critical perspective from Latin America: an epistemic disobedience in the contemporary Occupational Therapy. Cadernos Brasileiros de Terapia Ocupacional. 2016;24(2):421-7. https://doi.org//0.4322/2526-8910.ctoAOII82 
10. Guajardo A, Galheigo SM. Critical Reflections on Human Rights: Contributions from Latin American Occupational Therapy. World Federation of Occupational Therapists Bulletin. 2015;7I (2):73-80. https://doi.org/10.1 179/14473828 I5Z.00000000023

II. Silva CR. Direitos humanos para diversidade: construindo espaços de arte, cultura e educação [Human rights for diversity: building spaces for art, culture and education]. São Carlos: São Jorge; 2014.

12. Ambrosio L, Echeverría VR, Morrison R, Queiroz AG, Silva CR. La urgencia de una Terapia Ocupacional Antirracista [The urgency of an Anti-racist Occupational Therapy]. Revista de Estudiantes de Terapia Ocupacional 2021;8(I):i-xvii.

13. Silvestrini MS, Silva CR, Prado ACdSA. Occupational therapy and culture: ethical-political dimensions and resistances. Cadernos Brasileiros de Terapia Ocupacional. 2019;27(4):929-40. https://doi.org/10.4322/2526-89/0.ctoARF I 727

14. Morrison R, Araya L. Feminism(s) and Occupational Therapy. Questions and reflections. Revista Argentina de Terapia Ocupacional. 2018;4(2):60-72. https://www.terapia-ocupacional.org.ar/revista/ RATO/20I8dic-conf.pdf

15. Mota LdA. Social issue, and social policy neo-developmentism: critical notes. Polemica. 2015;15:01-12. https://doi.org/I0.1590/SOI0I-662820I 2000400002

16. Ugá VD. A questão social como pobreza [The social issue as poverty]. Curitiba: Appris; $201 \mathrm{I}$.

17. Lopes RE, Malfitano AP, Silva CR, Borba P. History, concepts and proposals in social occupational therapy in Brazil. Revista Chilena de Terapia Ocupacional. 2015; I5(I):73-84. https://doi.org/10.5354/07/9-5346.2015.37/32

18. Bianchi PC, Malfitano APS. Brazilian social occupational therapy and propositions in the social area: what do Latin American teachers say? TOG (A Coruña). 2017(26):8.

19. Malfitano APS, Lopes RE, Magalhães L, Townsend EA. Social occupational therapy. Canadian Journal of Occupational Therapy. 20 I4;8I (5):298-307. https://doi.org/I0. I I77/00084 I74 I45367/2

20. Barros DD, Ghirardi MIG, Lopes RE. Social Occupational Therapy. Revista de Terapia Ocupacional da Universidade de São Paulo. 2002; |3(3):95-103. https://doi.org/10.1 |606/issn.2238-6|49. v13i3p95-103

21. Coffito. No. 366, de 20 de maio de 2009, publicada no DOU n ${ }^{\circ} .112$, Seção I, em 16 de junho 2009, página 42. Brasil: Brasil; 2009.

22. Van der Merwe T. Occupational therapy and the quest for human dignity: Why human rights matter. South African Journal of Occupational Therapy. 2010;40(I):17-21.

23. Sato MT, Barros DD. Culture, mobility and human rights: considerations on social occupational therapy in the context of immigrants. Cadernos Brasileiros de Terapia Ocupacional. 2016;24(I). https://doi.org/10.4322/0104-493 I.ctoAO0756

24. Teixeira RSF, García MAS. Intervention from occupational therapy with refugees: bibliographic review. TOG (A Coruña). 2017(26):21. http://www.revistatog.com/num26/pdfs/revision3.pdf

25. Iwama MK. The Kawa model: Culturally relevant occupational therapy. Atlanta: Elsevier; 2006.

26. Zango I, Flores JA, Moruno P, Björklund A. Occupational therapy culture seen through the multifocal lens of fieldwork in diverse rural areas. Scandinavian Journal of Occupational Therapy. 2015;22(2):8294. https://doi.org/10.3109/1 1038128.2014.965197

27. Gonçalves MV, Costa SLd, Takeiti BA. Perspectives of culture and cultural citizenship in the academic community: student readings on the subject. Revista Argentina de Terapia Ocupacional. 2019;5(I):37-44.

28. Silva CR. Atividades Humanas e Terapia Ocupacional: Saber-fazer, cultura, política e resistências [Human Activities and Occupational
Therapy: Know-how, culture, politics and resistance]. São Paulo: Hucitec; 2019.

29. Silva CR, Cardinalli I, Sanches Silvestrini M, Zacchi Farias A, da Silva Almeida Prado A, Ambrosio L, et al. Occupational therapy and culture: perspectives toward social transformation. Revista Chilena de Terapia Ocupacional. 2017; 17(1): 105-13. https://doi.org//0.5354/07/9-5346.2017.46383

30. UNESCO. Declaración de México sobre políticas culturales [Declaration of Mexico on cultural policies], 1982. http://diversidadaudiovisual.org/declaracion-de-mexico-sobre-politicas-culturales- 1982/

31. Dorneles PS. Young people, territory and territoriality: aesthetic experiences and engagement in cultural actions in the cultural points of the South region. Políticas Culturais em Revista. 2014;7(2): 136-52. http://dx.doi.org// 0.977I//983-37 I 7pcr.v7i2.12575

32. Ferigato $\mathrm{SH}$, Silva CR, Lourenço GF. Cyberculture and Occupational Therapy: Creating Connections. South African Journal of Occupational Therapy. 2017;47(2):45-8.

http://dx.doi.org/10.17/59/231-3833/1017/v47n2a8

33. Chaura LE, Zorzoli FJM. Televisión digital desafíos del proceso en Argentina: comunicación, participación social y derechos humanos [Digital television challenges of the process in Argentina: communication, social participation and human rights]. In: Santos V, Gallassi $A D$, editors. Questões contemporâneas da Terapia Ocupacional na América do Sul [Contemporary Questões da Terapia Occupacional na América do Sul]. Curitiba: CRV; 2014. p. 185-204.

34. Engelen A-M, Silva CR, Martín IZ, Cloete LG, Schiller S, Kagwiza JN, et al. Community Development in Occupational Therapy Education: Learning From Global Experiences. Teaching and Learning Practices That Promote Sustainable Development and Active Citizenship: IGI Global; 202I. p. 276-305.

http://dx.doi.org/I0.40I8/978-I-7998-4402-0.ch014

35. Correia RLCL. Envolvimento ocupacional, analfabetismo urbanístico e interdisciplinaridade: A terapia ocupacional para as cidades pelas ideias da Erminia Maricato [Occupational involvement, urban illiteracy and interdisciplinary: To occupational therapy for ascities pelas ideias da Erminia Maricato]. Revista Políticas Públicas \& Cidades-2359-1552. 2021; 10(1). https://doi.org/I0.23900/2359-I552v I On I-maricato-4-202 I\%20

36. Bianchi PC, Malfitano APS. Occupational therapy in Latin America: Conceptual discussions on territory and community. Scandinavian Journal of Occupational Therapy. 2020:1-19. https://doi.org//0.1080/I 1038I28.2020.1842492

37. Silva ACCd, Oliver FC. Social participation in occupational therapy: what are we talking about? Cadernos Brasileiros de Terapia Ocupacional. 2019;27(4):858-72. https://doi.org//0.4322/2526-89/0. ctoARI883

38. Correia RL, Pulido JS, Ramrez RR. Terapia Ocupacional comunitária: entre o geral e o específico [Community Occupational Therapy: between o general and o specific]. In: Oliveira FNG, Takeiti BA, Araujo CRC, editors. Terapia Ocupacional: saberes e fazeres [Occupational Therapy: knowledge and factors]. Curitiba: Brazil Publishing; 2021 . p. 449-7I.

39. Bianchi PC. Terapia Ocupacional, território e comunidade: desvelando teorias e práticas a partir de um diálogo latino-americano [Occupational therapy, territory and community: unveiling theories and practices from a Latin-American dialogue]. São Carlos: [Thesis]. Doutorado em Terapia Ocupacional. Universidade Federal de São Carlos.; 2019.

40. Tolvett MP. Reflections on community practices: approach to an Occupational Therapy of the South. Revista Ocupación Humana. 2017; I7(I):73-88. https://doi.org/10.25214/25907816.157 
4I. Vinzón V, Allegretti M, Magalhães L. An overview of occupational therapy community practices in Latin America. Cadernos Brasileiros de Terapia Ocupacional. 2020;28:600-20.

https://doi.org/I0.4322/2526-89/0.ctoARI89I

42. García-Ruiz S, Vásquez A, Guajardo A. Rehabilitación Basada en la Comunidad: Una estrategia local para el acceso a derechos y el ejercicio de la ciudadanía. Lecturas latinoamericanas [Community-Based Rehabilitation: A Local Strategy for Access to Rights and the Exercise of Citizenship. Latin American readings]. Santiago: USACH; 2019.

43. Costa SLd. Social Occupational Therapy: matters and action possibilities with Traditional Peoples and Communities. Cadernos de Terapia Ocupacional da UFSCar. 2012;20(I).

http://dx.doi.org/I0.4322/cto.20I2.005

44. Macedo DC. Jovens entre culturas: itinerários e perspectivas de jovens Guarani a aldeia Boa Vista e a cidade de Ubatuba [Young people between cultures: itineraries and perspectives of young Guarani to the village of Boa Vista and to the city of Ubatuba]. São Paulo: [Thesis] Mestrado em Ciências). Universidade de São Paulo; 2010.

45. Gonçalves MV. A mobilidade urbana de jovens em projetos sociais do complexo do alemão, no rio de janeiro, e suas relações com a terapia ocupacional social [Urban mobility of young people in social projects of the German complex, not Rio de Janeiro, and their relationships with social occupational therapy]. Sao Carlos: [Thesis] Doutorado em Terapia Ocupacional. Universidades Federal de Sao Carlos; 2020.

46. Paganizzi L. Terapia ocupacional psicosocial: escenarios clínicos y comunitarios [Psychosocial occupational therapy: clinical and community settings]. Buenos Aires: Polemos; 2007.

47. Santos BDS. Southern epistemologies. Utopia and Latin American praxis. 201 I; 16(54):17-39.

48. Valderrama C. South occupational therapies: a proposal for its understanding. Cadernos Brasileiros de Terapia Ocupacional. 2019;27(3). https://doi.org/10.4322/2526-89/0.ctoARFI859

49. Simó S, Guajardo A, Corrêa F, Galheigo S, García-Ruíz S, editors. Terapias Ocupacionales desde el Sur. Derechos humanos, ciudadanía y participación [Occupational Therapies from the South. Human rights, citizenship and participation]. Santiago: Editorial USACH; 2016.

50. Silva CR, Morrison R, Calle Y, Kronenberg F. Occupational Therapies of the South: current demands from a socio-historical perspective. Revista Interinstitucional Brasileira de Terapia Ocupacional. 2019;3(2): 172-8.

5I. Queiroz AG, Castro LR, Jara RM. Ciência Ocupacional: perspectivas gerais e propostas para a América Latina [Occupational Science: general perspectives and proposals for Latin America]. In: Petten A, Cardoso A, Brito M, editors. Fazer, ser e tornar-se: Desafios e Possibilidades no Estudo da Ocupação [Doing, being and becoming: Challenges and Possibilities in the Study of the Occupation]. Minas Gerais: (In press); 2021.

52. Caro-Vines P, Morrison R, Palacios M. Cincuenta años de terapia ocupacional en Chile: prácticas, epistemologías y realidades locales [Fifty years of occupational therapy in Chile: practices, epistemologies and local realities]. Santiago, Chile: Colegio de Terapeutas Ocupacionales de Chile; 2020.

53. Morrison R, Gomez S, Henny E, Tapia MJ, Rueda L. Principal Approaches to Understanding Occupation and Occupational Science Found in the Chilean Journal of Occupational Therapy (200I-20I2). Occupational Therapy International. 2017.

https://doi.org/10.1 I55/2017/5413628

54. Álvarez E, Gómez S, Muñoz I, Navarrete E, Riveros ME, Rueda L, et al. Definition and development of the concept of occupation: an essay on the experience of theoretical construction from a local identity. Revista Chilena de Terapia Ocupacional. 2007;7(I):76-82. https://doi.org/10.5354/0719-5346.2010.81

55. Carrasco J, Olivares D. Making the path to the floor: construction and understanding of Occupation for the investigation and practice of Occupational Therapy. Revista Chilena de Terapia Ocupacional. 2008;8:5-16. https://doi.org/10.5354/0719-5346.2010.55

56. Apablaza M. Inclusion in education, occupational marginalization and apartheid: An analysis of Chilean education policies. Journal of Occupational Science. 2018;25(4):450-62.

57. Carrasco J. Political dimensions in the actions of health-care practitioners: Reflections for occupational science based on the Chilean psychiatric reform. Journal of Occupational Science. 2018;25(4):50919. https://doi.org/10.1080/14427591.2018.1519869

58. Yanez R, Zuniga Y. The law and occupational justice: Inputs for the understanding of disability in Chile. Journal of Occupational Science. 2018;25(4):520-9. https://doi.org/10.1080/14427591.2018.1522945

59. Caro-Vines P. Occupation: Knowledge from the practice of Occupational Therapists with major trayectoria in the Region of Araucania. Revista Chilena de Terapia Ocupacional. 2018;18(I):69-78. https://doi.org/10.5354/07/9-5346.2018.50367

60. Munoz CG. Challenges in occupational justice and social inclusion: Selected experiences within Valdivia's civil society. Journal of Occupational Science. 2018;25(4):486-96. https://doi.org/10.1080/I4427591.2018.1517404

6I. Avillo C, Barrientos B, Fernández J, Matus C, Olivares C, Morrison R. Context and Occupational Choices of Adolescents Identifying as Homosexuals. Revista Chilena de Terapia Ocupacional. 2015; I 5(2): I - 19. https://doi.org/10.5354/07| 9-5346.20I5.38I57

62. Morrison R, Araya L, Valle JD, Vidal V, Silva K. Occupational apartheid and human rights: Narratives of Chilean same-sex couples who want to be parents. Journal of Occupational Science. 2020;27(I):39-53. https://doi.org//0.1080//4427591.2020.1725782

63. Morrison R, Olivares D, Vidal D. The Philosophy of Human Occupation and the Social Paradigm of Occupation. Some reflections and proposals on current epistemologies in Occupational Therapy and Occupational Sciences. Revista Chilena de Terapia Ocupacional. 20 I I; I (2): I02-19. https://doi.org/10.5354/07 I9-5346.20 I I. I 7785

64. Trujillo Rojas A, Sanabria Camacho L, Carrizosa Ferrer L, Parra Esquivel E, Rubio Viscaya S, Uribe Sarmiento J, et al. Ocupación: sentido, realizacion y libertad. Dialogos ocupacionales en torno al sujeto, la sociedad y el medio ambiente [Occupation: meaning, fulfillment and freedom. Occupational dialogues around the subject, society and the environment]. Bogotá: Editorial Universidad Nacional de Colombia; $201 \mathrm{I}$.

65. Magalhães L, Nayar S, Pizarro EP, Stanley M. Extending the paradigm: Occupation in diverse contexts. Journal of Occupational Science. 20।8;25(4):445-9. https://doi.org/10.1080/14427591.2018.1528846

66. Quijano A. Coloniality of power and social classification. Journal of world-systems research. 2000; I I (2):342-86.

67. Mignolo W. Desobediencia epistémica: retórica de la modernidad, lógica de la colonialidad y gramática de la descolonialidad [Epistemic disobedience: rhetoric of modernity, logic of coloniality and grammar of decoloniality]. Argentina: Ediciones del signo; 2010.

68. Ballestrin L. Latin America and the decolonial turn. Revista Brasileira de Ciência Política. 2013;11:89-1 17.

https://doi.org/I0.1590/S0I03-33522013000200004

69. Vaiano B. Como a indústria dos artigos científicos trava o avanço da ciência [How to industry two scientific artigos work or advance the science]. Super Interessante. 2020. 
https://super.abril.com.br/ciencia/a-maquina-que-trava-a-ciencia/

70. Cezar da Cruz DM, Denubila Costa J, Veiga J, Gurian Manzini M, de Araujo Costa Folha OA. Current electronic journals on occupational therapy: A descriptive study. Revista de la Facultad de Medicina. 2019;67(3):249-54.

https://doi.org/10.15446/revfacmed.v67n3.66778

7I. Folha OAdAC, Folha DRdSC, Cruz DMCd, Barba PCdSD, Emmel MLG. An overview of occupational therapy publication in non-specific professional journals in the period of 2004 to 20151. Cadernos Brasileiros de Terapia Ocupacional. 2019;27(3):650-62. https://doi.org/10.4322/2526-8910.ctoAOI700

72. Krenak A. Ideias para adiar o fim do mundo [Ideias para adiar o fim do mundo]. São Paulo: Companhia das Letras; 2019.

73. Monzeli GA, Morrison R, Lopes RE. Histories of occupational therapy in Latin America: the first decade of creation of the education Programmes. Cadernos Brasileiros de Terapia Ocupacional. 2019;27(2):235-50. https://doi.org/ 10.4322/2526-89 I0.ctoAOI63 I

74. Rodrigues $\mathrm{C}$. Gender issues in and for democracy. Ciência e Cultura. 2017;69(I):30-4.

http://dx.doi.org/10.2I800/23 I7-66602017000I000I3

75. Han GWS. Local development: challenges facing hegemonic globalization. Vitrine da Conjuntura. 2009;2(2): I-12.

\section{Corresponding Author}

\section{*Rodolfo Morrison}

Email: rodolfo.morrison@uchile.cl 